\title{
REVISED Evolution of alarm cues: a test of the kin selection
}

\section{hypothesis [version 2; peer review: 2 approved with}

\section{reservations]}

Previously titled: Evolution of alarm cues: a role for kin selection?

\author{
Denis Meuthen, Sebastian A Baldauf, Timo Thünken
}

Institute for Evolutionary Biology and Ecology, University of Bonn, An der Immenburg, Bonn, D-53121, Germany

\author{
V2 First published: 11 Oct $2012,1: 27$ \\ https://doi.org/10.12688/f1000research.1-27.v1 \\ Latest published: 27 May 2014, 1:27 \\ https://doi.org/10.12688/f1000research.1-27.v2
}

\section{Abstract}

The evolution of alarm signals has puzzled evolutionary ecologists for decades. This is particularly true for alarm cues ('Schreckstoff') which are present in many fishes. They are passively released through injuries and signal the presence of a predator. Although the benefits for conspecific receivers are obvious (they can adjust their behavior to avoid predation), those for the senders are not which is, however, a necessary requirement for the evolution of alarm signals. Several hypotheses relying on potential direct benefits for the senders have been suggested. Alarm cues might attract secondary predators which in turn might increase the escape probability of the sender. A primary immune enhancing role was suggested as well. An alternative explanation is based on Hamilton's inclusive fitness theory stating that individuals can indirectly increase their fitness by increasing the survival of genetically related individuals ('kin selection theory'). If related individuals preferentially benefit from alarm signals, for instance by being more receptive to kin-alarm cues, senders could increase their inclusive fitness. Here, we investigate whether individuals of the cichlid fish Pelvicachromis taeniatus respond differentially to alarm cues derived from kin and non-kin. $P$. taeniatus possesses alarm cues and is known to adjust its behavior when exposed to alarm cues. We measured the change in activity after the addition of alarm cues (derived from kin- and non-kin) relative to a control treatment. Reduced activity is a widespread behavioral adaptation to reduce predation risk in prey organisms. Fish of the alarm cue treatments significantly reduced their activity relative to control fish. However, fish did not respond differentially to alarm cues derived from kin and non-kin suggesting that potential inclusive fitness benefits are not mediated by responses specific to individual alarm cues. We discuss alternative mechanisms such as kin shoaling and mating preferences potentially leading to kin-biased alarm cue perception.

\begin{tabular}{lcc} 
Open Peer Review & \\
Approval Status & $?$ & 2 \\
\hline & 1 & \\
version 2 & $?$ & $?$ \\
(revision) & view & view \\
27 May 2014 & $?$ & $?$ \\
version 1 & $?$ & $?$ \\
11 Oct 2012 & view & view
\end{tabular}

1. Dustin Rubenstein, Columbia University,

New York, NY, USA

2. Maurice W Sabelis, University of Amsterdam, Amsterdam, The Netherlands

Martijn Egas, University of Amsterdam,

Amsterdam, The Netherlands

Paulien JA de Bruijn, University of

Amsterdam, Amsterdam, The Netherlands

Any reports and responses or comments on the article can be found at the end of the article. 
Corresponding author: Denis Meuthen (dmeuthen@evolution.uni-bonn.de)

Competing interests: No competing interests were disclosed.

Grant information: This research was funded by the Deutsche Forschungsgemeinschaft (TH 1615/1-1).

The funders had no role in study design, data collection and analysis, decision to publish, or preparation of the manuscript.

Copyright: ( $) 2014$ Meuthen D et al. This is an open access article distributed under the terms of the Creative Commons Attribution License, which permits unrestricted use, distribution, and reproduction in any medium, provided the original work is properly cited. Data associated with the article are available under the terms of the Creative Commons Zero "No rights reserved" data waiver (CC0 1.0 Public domain dedication).

How to cite this article: Meuthen D, Baldauf SA and Thünken T. Evolution of alarm cues: a test of the kin selection hypothesis [version 2; peer review: 2 approved with reservations] F1000Research 2014, 1:27 https://doi.org/10.12688/f1000research.1-27.v2

First published: 11 Oct 2012, 1:27 https://doi.org/10.12688/f1000research.1-27.v1 


\section{REVISED Amendments from Version 1}

Both reviews raised concerns about the premise of our study. We argue that the premise of our study based on kin section theory is theoretically sound and empirically realistic. However, we agree that the potential underlying mechanisms could have been detailed more specifically. We address this aspect in the revised version.

The production of alarm cues has been shown to be costly. Assuming no direct fitness benefits for the sender, both alarm cue production and its release can be considered an altruistic act because it increases the fitness of receivers at the expense of the sender. However, reciprocal "altruism" (cooperation) is unlikely because the sender is seriously harmed. In this case, the production of costly public goods should be strongly selected against. A solution to this problem would be that the sender can indirectly increase its fitness if the receivers, and thus beneficiaries, are genetically related to the sender. As alarm cues are released passively via the destruction of cells upon a predatory attack, active signaling by the sender towards kin is unlikely. However, receivers may respond better to alarm cues produced by relatives. This is realistic as fishes are highly sensitive to kin cues and a concurrent presence of alarm cues and kin cues after a predation event is likely. An enhanced response to alarm cues in the presence of kin cues may result in relatives being able to respond to predation more quickly or more intensely and thus increase their survival. Such kin-specific responses are not confined to animals. Even in plants, volatile cues emitted by wounded closely related neighbors induced stronger response than those emitted by less closely related neighbors (Karban et al. 2013 "Kin recognition affects plant communication and defence" Proc R Soc Lond B, 280, 20123062).

See referee reports

\section{Introduction}

Alarm signals are cues emitted by individuals in the presence of predators. These signals may not only divert predator attention or discourage it to attack but also alert conspecifics ${ }^{1}$. Alarm signals can be transmitted via different communication pathways: alarm calls are widespread among social terrestrial animals (rodents ${ }^{2}$, birds $^{3}$ and primates ${ }^{4}$ ). Other animal species use alarm pheromones for the same purpose (insects ${ }^{5,6}$ or mice ${ }^{7}$ ). In aquatic species, chemical alarm signals are widespread especially due to the large number of water-soluble compounds ${ }^{8}$ (insects $^{9}$, crustaceans $^{10}$, asteroids ${ }^{11,12}$, gastropods ${ }^{13,14}$, amphibians ${ }^{15,16}$ and fishes ${ }^{17}$ ). Alarm signaling is usually costly for the individual sender ${ }^{18}$ and often appears to primarily benefit the receivers. However, to evolve and be maintained by natural selection, the fitness benefits for the signaling individual must override its costs. One hypothesis proposed to explain the evolution of alarm signals is that senders benefit via reciprocal cooperation ${ }^{19}$. By this mechanism, the higher risk taken upon an individual during signaling is reciprocated by one of the receivers. On the other hand, many animals live in kin groups ${ }^{20}$ and it has been suggested that the process of kin selection is a major factor during the evolution of alarm signals. The term 'kin selection', coined by Maynard-Smith ${ }^{21}$ summarizes one aspect of Hamilton's inclusive fitness theory, which predicts that individuals can increase their fitness indirectly by supporting the survival of genetically related individuals ${ }^{22}$. This process facilitates the evolution of costly communication ${ }^{23}$ and it may contribute to the evolution of alarm signals. For instance, it has been suggested that kin selection plays an important role in the evolution of mammalian alarm calls $\mathrm{s}^{2,25-27}$ (but $\mathrm{see}^{28}$ ). Furthermore, kin-specific alarm responses have been reported during the chemical alarm communication of plants. Karban et al. ${ }^{24}$ describe that sagebrush plants induce increased protection mechanisms against herbivores when exposed to the volatile cues of wounded close relatives in comparison to plants exposed to cues from distantly related individuals.

The evolution of chemical alarm cues which are widespread in fishes ${ }^{29}$ is a particularly puzzling example of alarm signaling whose evolution has intrigued evolutionary ecologists since the 1960ies ${ }^{30,31}$ until today ${ }^{32}$. Chemical alarm cues, also termed 'Schreckstoff' 33,34 , are assumed to be located in specialized enclosed epidermal 'club cells' without external ducts ${ }^{29,35,36}$ (but see $^{37}$ ) and are passively released following injuries by predators, a likely lethal event. Because alarm cues are energetically costly to produce ${ }^{38}$ and reciprocal cooperation is unlikely because most senders will not survive a predator attack (leaving them unable to become a recipient of a reciprocal action), the evolution and maintenance of such communication remains obscure. Receivers benefit greatly because the presence of alarm cues reliably indicates high predation risk, thus allowing them to respond to predator presence and thereby increasing their survival probability ${ }^{39,40}$. Nevertheless, the benefits to the signaler often remain unclear considering its low survival probability when attacked. Still, most hypotheses proposed to explain the evolution of alarm cues in fishes focus on direct benefits to the sender ${ }^{41,42}$. Alarm cues might increase the survival of the producing individual. In this context, it has been suggested that alarm pheromones may function to attract secondary predators ${ }^{43}$. During the following interference between competing predators prey might be able to escape. Mathis et al..$^{43}$ showed that pike Esox lucius and predatory diving beetles (Dytiscidae) were indeed attracted by minnow alarm cues. In the presence of such secondary predators (pike), escape probabilities of minnows were actually increased ${ }^{44}$. Accordingly, the signaling individual can increase its own fitness by producing alarm cues, provided that it survives an initial predator attack. Other authors proposed that the alarm function is a mere by-product and instead suggested the primary function of alarm cues to be anti-pathogenic agents ${ }^{45}$ or promote the healing of injuries ${ }^{46}$. A recent study by Chivers et al. ${ }^{47}$ supported this hypothesis; club cell production was unrelated to predation risk but stimulated by skin penetrating pathogens and parasites (but see ${ }^{48}$ ). Moreover, Chivers et $a l .{ }^{47}$ found that UV radiation also affected club cell production, providing evidence for a general immune function of club cells.

Similar to mammalian alarm calls ${ }^{2,25-27}$ and plant volatile alarm cues $^{24}$, kin selection has been proposed to explain the evolution of alarm cues in fishes ${ }^{42}$. Nevertheless, this hypothesis has received little attention ${ }^{49}$. Previous studies have shown that in aquatic species that use chemical alarm cues to detect predator signals such as gastropods $^{50}$, amphibians ${ }^{51,52}$ and fish ${ }^{53}$, the magnitude of the response to heterospecfic alarm cues was positively correlated to the sender - receiver phylogenetic similarity. Accordingly, graded responses dependent on the degree of genetic relatedness within a species might appear as well. Furthermore, alarm cues are a mixture of many different substances ${ }^{54}$ and as only single active components have been identified to date ${ }^{54-56}$, their exact composition remains elusive. That leaves the potential that the substances emitted from injured fish contain kin-specific cues. Earlier studies have indeed suggested that alarm cues vary between senders ${ }^{57}$ and that individuals differentially respond to different alarm signals. For instance, familiarity 
with specific alarm calls ${ }^{58}$ or chemical cues ${ }^{59,60}$ was shown to lead to improved responses. Higher sensitivity to alarm cues released by kin may thus result in an improved response to predation, and thus higher survival of individuals related to the sender which in turn may increase the indirect fitness of the sender.

Two possible mechanisms could cause such beneficial kin-specific alarm responses. Kin alarm cues could be identified directly (when alarm cues include a kin-specific component) or indirectly (when alarm cues do not include such kin-specific components but are perceived simultaneously with the kin cues of the sender). Little is known about the molecular basic of alarm cues in general; consequently, even less concerning potential kin-specific patterns. On the other hand, kin recognition based on chemical cues is widespread in animals ${ }^{61}$. Such kin-cues are often more or less continuously emitted by individuals, e.g. via the urine. As fish readily associate alarm cues with other cues such as chemical cues ${ }^{62-65}$ or visual cues $^{66}$ from heterospecifics, a successful association between alarm cues and concurrently present kin-related cues might be possible. This combination might then trigger stronger responses than alarm cues perceived with unknown cues.

The aim of the present experiment was to test whether the cichlid fish Pelvicachromis taeniatus responds more strongly to alarm cues produced by kin than to those produced by non-kin. P. taeniatus is a socially monogamous small cave-breeder with biparental brood care $^{67}$ which inhabits streams in Western Africa ${ }^{68}$. Previous studies revealed that this species possesses alarm cues, recognizes conspecific alarm cues and adjusts its behavior in the presence of alarm cues (DM, SAB, Theo C. M. Bakker, TT, unpublished data). Furthermore, $P$. taeniatus is capable of kin recognition ${ }^{69-71}$ which is most likely based on chemical cues ${ }^{72-75}$. In the experiment we measured the change in activity in individual P. taeniatus after the addition of alarm cues derived from kin and non-kin, respectively.

\section{Material and methods}

Ethics statement

This study conforms to the Association for the Study of Animal Behaviour's Guidelines for the Use of Animals in Research and was carried out according to the German laws for experimentation with animals ( $\S 8$ Abs. 1 TierSchG, V.m. $§ 2$ Abs. 1.1 TierSchZustV NW 26.9.1989). No additional licenses were required.

\section{Animal collection and maintenance}

We conducted an experiment using female F2 progeny of the cichlid species $P$. taeniatus, whose ancestors (F0) were collected from the Moliwe river near Limbe, Cameroon $\left(04^{\circ} 04^{\prime} \mathrm{N}, 09^{\circ} 16^{\prime} \mathrm{E}\right)$. Female $P$. taeniatus were used exclusively due to their consistent activity levels relative to males ${ }^{76}$. Prior to experiments, fish were kept in mixed-sex $50 \times 30 \times 30 \mathrm{~cm}(\mathrm{~L} \times \mathrm{W} \times \mathrm{H})$ stock tanks at densities up to 20 individuals and were fed daily with frozen invertebrate larvae ad libitum. These tanks were illuminated in a 12:12 h light:dark cycle; water temperature was kept at $25 \pm 1^{\circ} \mathrm{C}$.

\section{Experimental setup}

During experiments, we exposed individual fish to one of the following extracts: (1) Alarm cues derived from kin (from familiar and unfamiliar siblings); (2) Alarm cues derived from unfamiliar, unrelated conspecifics (non-kin); (3) Distilled water to control for disturbance effects upon introduction. We produced alarm cues from 26 lab-bred donor cichlids which were previously starved for two days to exclude any effects caused by the individual's selective diet. Each alarm cue consisted of a male and a female cichlid to control for sex effects. Fish were anaesthetized with a blow to the head and afterwards euthanized by cervical dislocation in accordance to $\S 4$ of the German animal welfare act (BGB 1. I S. 1207, 1313). The whole fish were then grinded in a mortar using a pestle. This procedure ruptured cells and thus allowed alarm pheromones to be released. By using whole fish, we additionally accounted for the possible existence of alarm cues located outside the skin (e.g. blood cues ${ }^{37}$ ). Furthermore, such assays are also likely to contain kin-specific chemical cues (e.g. in the urinary system). The homogenate was diluted with distilled water, passed through filter floss and frozen in $1 \mathrm{ml}$ aliquots at $-20^{\circ} \mathrm{C}$ until use. The final concentration each fish was exposed to during trials was $3.6 \mathrm{mg} / \mathrm{l}$ donor wet fish weight. Likewise, we prepared $1 \mathrm{ml}$ aliquots of pure distilled water for control experiments.

Trials were run in $30 \times 20 \times 20 \mathrm{~cm}$ tanks which were supplemented with a $0.5 \times 0.5 \times 15 \mathrm{~cm}$ grey square plastic tube leading $5 \mathrm{~cm}$ below the water level at the middle of their short side. This duct allowed the direct addition of chemical cues into the tanks while minimizing fish disturbance. Furthermore, experimental tanks were surrounded on all sides (except the top) with white polystyrene to prevent fish agitation by neighboring fish or the experimenter. A video camera (QuickCam 9000, Logitech, China) viewing the tanks from the top enabled recording of fish behavior for evaluation. Tanks were filled with substrate-treated water at $24^{\circ} \mathrm{C}^{7}$; individual fish were then introduced and acclimatized for $1 \mathrm{~h}$, this period is referred to as the pre-stimulus phase from now on. Experimental stimuli were thereafter temperatureadjusted to tank conditions and introduced at the point of $1 \mathrm{~h} 15 \mathrm{~min}$. Subsequently, fish behavior was recorded for another hour. Afterwards, the experimental subjects were sized accurate to the nearest millimeter (standard length: body size from snout to the beginning of the tail fin) and weighed accurate to one milligram on a digital precision scale (LC 2215, Sartorius, Germany). Between trials, tanks were cleaned with $3 \%$ hydrogen peroxide and then rinsed with tap water to remove remaining olfactory traces ${ }^{77,78}$. Furthermore, experimental stimuli assigned to individual tanks were alternated between trials.

In total, we tested 51 individuals from 8 families; extracts from the same donor fish were used throughout different treatments and thus represented - based on the family identity of the focal fish - either kin or non-kin alarm cues. Also, individuals from the same family were evenly distributed among the three extracts. In two cases the fish exhibited no activity during the pre-stimulus phase and were excluded from analysis. Hence, the final sample size consisted of 49 individuals; 12 received alarm cues from familiar siblings, 9 from unfamiliar siblings, 14 from unrelated fish and 14 individuals were exposed to the control stimulus. Because sibling familiarity did not significantly affect focal fish activity (familiar $v s$. unfamiliar kin: $\chi^{2}=0.090$, $\mathrm{p}=0.764$ ), their activity scores were pooled to represent 21 fish receiving alarm cues derived from kin.

\section{Statistical analysis}

We evaluated fish activity by tracking its movement during the $1 \mathrm{~h}$ pre-stimulus phase and the following $1 \mathrm{~h}$ post-stimulus phase with 
animal tracking software (Biobserve Viewer ${ }^{2}$ 3.0.0.119, St. Augustin, Germany). Subsequently, we assigned an activity index to each fish by calculating the difference between the distances covered during the two experimental phases. All statistical analyses were conducted using R 3.0.179. Neither body size nor weight nor activity indices deviated significantly from normal distribution according to the Kolmogorov-Smirnov test with Lilliefors significance correction (Lillie.test, R library 'nortest'), thus we applied linear-mixed effect models (LME, R library 'nlme') for analysis. All test fish were only used once but to account for the repeated use families, we entered 'family identity' as a random factor. All results were based on likelihood ratio tests (LRT); hence degrees of freedom differed by two in analyses involving all three treatments and by one in the analyses testing for differences between two treatments.

\section{Results}

Fish activity before the introduction of the three treatments was not significantly different among the three groups $\left(\chi^{2}=4.398\right.$, $\mathrm{p}=0.111)$. Moreover, neither fish standard length $\left(\chi^{2}=0.648, \mathrm{p}=\right.$ $0.723)$ nor body mass $\left(\chi^{2}=0.498, \mathrm{p}=0.780\right)$ differed significantly between treatments. However, the change in activity of female $P$. taeniatus was significantly affected by the treatment $\left(\chi^{2}=10.057\right.$, $\mathrm{p}=0.007$, Figure 1). Activity indices of both alarm-cue treatment groups (kin/non-kin) were significantly different from those of the water-control group (Kin $v s$. water: $\chi^{2}=8.346, \mathrm{p}=0.004$; Non-kin vs. water: $\chi^{2}=8.693, \mathrm{p}=0.003$, Figure 1$)$. Fish of the control group showed on average an increase of $6.7 \mathrm{~m}$ in covered distance during the post-stimulus period, whereas fish of both alarm cue treatments

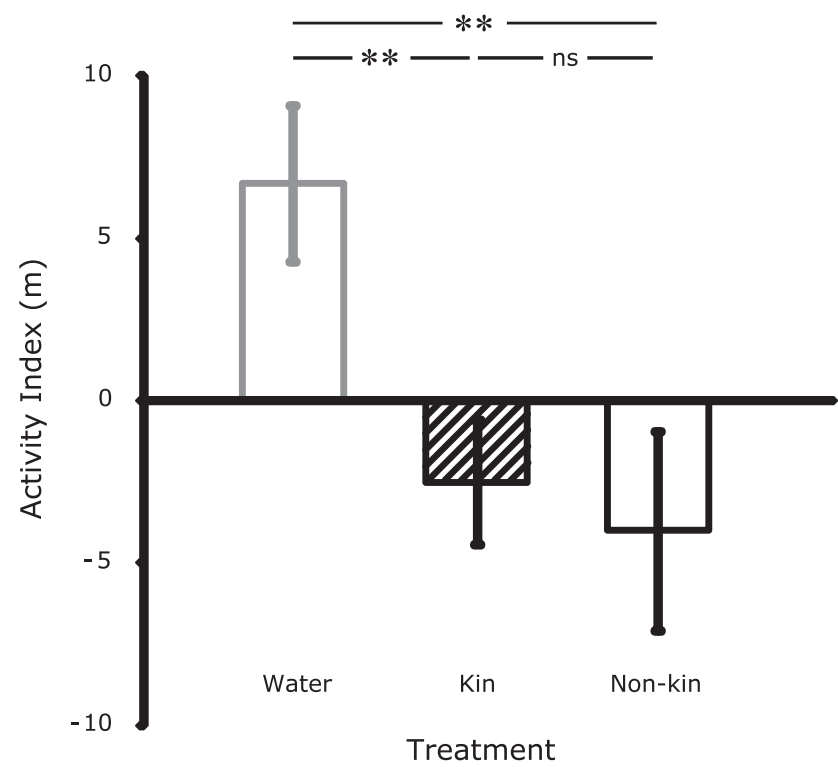

Figure 1. Activity indices of female $P$. taeniatus (mean \pm SE) exposed to distilled water (gray open bar) and alarm cues derived from related conspecifics (kin, black hatched bar) or unrelated conspecifics (non-kin, black open bar). Activity indices were calculated by subtracting the distance covered during the $1 \mathrm{~h}$ prestimulus phase from the following $1 \mathrm{~h}$ poststimulus period. Asterisks above the bars indicate ${ }^{* *} p<0.01$; ns $p>0.6$. showed reduced activity in the post-stimulus phase (on average $3.1 \mathrm{~m}$ less compared to the pre-stimulus phase). However, fish did not respond differently to alarm cues derived from related and unrelated individuals $\left(\chi^{2}=0.233, \mathrm{p}=0.630\right.$, Figure 1$)$.

\section{Fish activity data: Update 1}

1 Data File

http://dx.doi.org/10.6084/m9.figshare.1031544

\section{Discussion}

Generally, activity of female $P$. taeniatus was affected by the presence of conspecific alarm cues. Fish of the alarm cue treatment significantly decreased their activity relative to control fish. However, $P$. taeniatus did not respond differentially to alarm cues derived from kin or non-kin in terms of activity changes.

First, these results are in accordance to numerous studies showing that the presence of conspecific alarm cues decreases prey activity in general ${ }^{80,81}$. Reduced activity concurrently decreases prey conspicuousness, which is an effective strategy against visual predators and enhances survival ${ }^{81}$. Furthermore, our results add to an earlier study, showing that males of $P$. taeniatus reduce territorial aggression in the presence of conspecific alarm cues (DM, SAB, Theo C. M. Bakker, TT, unpublished data). Thus both sexes of $P$. taeniatus are capable of recognizing alarm cues and adjust their behavior accordingly.

Against the expectations of the kin selection hypothesis, fish did not discriminate between kin and non-kin alarm cues. These results are also in contrast to other studies that found kin-biased responses concerning alarm signals in plants ${ }^{24}$ or mammals ${ }^{2,25-27}$ (but see ${ }^{28}$ ). As alarm cues are assumed to be located inside enclosed epidermal 'club cells' without external ducts ${ }^{29,35,36}$ (but see ${ }^{37}$ ), they constitute a passively released discrete signal probably sent only once during an individual's lifetime. This makes reciprocal cooperation unlikely in the case of fish alarm cues. Consequently, this result rather suggests that the evolutionary origin of alarm cues in fishes is based on direct benefits to the sender ${ }^{42}$, including those hypotheses highlighting that alarm cues might have primarily evolved as an immune enhancing mechanism, making the alarm signal function a by-product ${ }^{47}$.

The missing discrimination between different alarm cues suggests that a) cues signaling the presence of kin are not part of the alarm system b) that fish did not link concurrently present alarm cues to kin cues or c) that kin cues were not recognized. As $P$. taeniatus have been shown to be capable of kin recognition ${ }^{69-71}$, it is likely that they have detected the presence of kin during trials (e.g. via urine, which was included in the fish extract). Thus, instead of missing kin recognition, our results rather suggest that kin-related cues and alarm cues are neither linked directly nor indirectly in P. taeniatus. The fitness benefits of kin discrimination in the context of alarm cue perception might be too small in order to generate selection on either senders or receivers. In fact, these benefits might 
be unable to outweigh possible additional production (kin-related information as an alarm cue component) or sensory costs (receiver coupling between concurrently present alarm cues and kin cues).

Alternatively, kin discrimination in alarm cues might simply not have evolved in P. taeniatus due to the lack of necessity. Many fishes are capable of identifying kin and live in kin-shaped groups ${ }^{82}$. This is also true for P. taeniatus which lives the first weeks after hatching in family groups guarded by their parents ${ }^{67}$. Afterwards they live in shoals without defined territories throughout the juvenile stage ${ }^{68}$. Laboratory experiments showed that they prefer to shoal with familiar kin (TT, Saskia Hesse, Theo C. M. Bakker, SAB, unpublished data) and that kin form tighter shoals ${ }^{83}$. Furthermore, $P$. taeniatus prefers to mate with kin $^{69}$ which is most likely also true for the natural population ${ }^{84}$. Accordingly, throughout their life the social environment of $P$. taeniatus is probably largely kin-structured in nature. In this case, individuals receiving the information transmitted by alarm cues are most likely kin due to the nature of the spatial distribution. As a consequence, signaling individuals might still increase their inclusive fitness according to the kin selection theory.

In conclusion, our study found no evidence for differences in response between alarm cues derived from kin or non-kin. However, under natural conditions behavioral mechanisms may lead to kin-biased alarm cue perception. Thus, kin selection potentially plays a role in alarm signaling in our model system. Still, further research is required determining the direct fitness benefits and costs for the signaling individual as well as the benefits for the receivers which are fundamental parameters to understand the evolution and maintenance of alarm cues.

\section{Data availability}

figshare: Fish activity data: Update 1, doi: 10.6084/m9.figshare. $1031544^{85}$

\section{Author contributions}

TT and DM conceived the study. DM, SAB and TT designed the experiments. DM carried out the research. DM, SAB and TT analysed the data. DM and TT wrote the paper. All authors had read and improved the manuscript and agreed to the final content.

\section{Competing interests}

No competing interests were disclosed.

\section{Grant information}

This research was funded by the Deutsche Forschungsgemeinschaft (TH 1615/1-1).

The funders had no role in study design, data collection and analysis, decision to publish, or preparation of the manuscript.

\section{Acknowledgements}

We are grateful to the Bakker research group for discussion.
1. Smith RJF: Evolution of alarm signals: Role of benefits of retaining group members or territorial neighbors. Am Nat. 1986; 128(4): 604-610. Reference Source

2. Sherman PW: Nepotism and evolution of alarm calls. Science. 1977; 197(4310): 1246-1253.

PubMed Abstract | Publisher Full Text

3. Klump GM, Shalter MD: Acoustic behavior of birds and mammals in the predator context; 1. Factors affecting the structure of alarm signals. 2. The functional significance and evolution of alarm signals. Z Tierpsychol. 1984; 66(3): 189-226. Publisher Full Text

4. Macedonia JM, Evans CS: Essay on contemporary issues in ethology: Variation among mammalian alarm call systems and the problem of meaning in animal signals. Ethology. 1993; 93(3): 177-197. Publisher Full Text

5. Blum MS: Alarm pheromones. Annu Rev Entomol. 1969; 14: 57-80. Publisher Full Text

6. Kunert G, Otto S, Rose USR, et al:: Alarm pheromone mediates production of winged dispersal morphs in aphids. Ecol Lett. 2005; 8(6): 596-603. Publisher Full Text

7. Rottman SJ, Snowdon CT: Demonstration and analysis of an alarm pheromone in mice. J Comp Physiol Psychol. 1972; 81(3): 483-490. PubMed Abstract | Publisher Full Text

8. Steiger S, Schmitt T, Schaefer HM: The origin and dynamic evolution of chemical information transfer. Proc R Soc Lond B. 2011; 278(1708): 970-979. PubMed Abstract | Publisher Full Text | Free Full Text

9. Sih A: Antipredator responses and the perception of danger by mosquito larvae. Ecology. 1986; 67(2): 434-441. Publisher Full Text

10. Laforsch C, Beccara L, Tollrian R: Inducible defenses: The relevance of chemical alarm cues in Daphnia. Limnol Oceanogr. 2006; 51(3): 1466-1472. Publisher Full Text

11. Parker DA, Shulman MJ: Avoiding predation: Alarm responses of Caribbean seaurchins to simulated predation on conspecific and heterospecific sea-urchins. Mar Biol. 1986; 93(2): 201-208. Publisher Full Text

12. Lawrence JM: A chemical alarm response in Pycnopodia helianthoides
(Echinodermata, Asteroidea). Mar Behav Physiol. 1991; 19(1): 39-44. Publisher Full Text

13. Sleeper HL, Paul VJ, Fenical W: Alarm pheromones from the marine opisthobranch Navanax inermis. J Chem Ecol. 1980; 6(1): 57-70. Publisher Full Text

14. Kempendorff W: Über das Fluchtphänomen und die Chemoreception von Helisoma (Taphius) nigricans). Arch Molluskenkd. 1942.

15. Hews DK, Blaustein AR: An investigation of the alarm response in Bufo boreas and Rana cascadae tadpoles. Behav Neural Biol. 1985; 43(1): 47-57. PubMed Abstract | Publisher Full Text

16. Kats LB, Petranka JW, Sih A: Antipredator defenses and the persistence of amphibian larvae with fishes. Ecology. 1988; 69(6): 1865-1870. Publisher Full Text

17. Wisenden $\mathrm{BD}$ : Olfactory assessment of predation risk in the aquatic environment. Philos Trans R Soc Lond B Biol Sci. 2000; 355(1401): 1205-1208. PubMed Abstract | Publisher Full Text | Free Full Text

18. Hughes AL: Evolution of adaptive phenotypic traits without positive Darwinian selection. Heredity (Edinb). 2012; 108(4): 347-353.

PubMed Abstract | Publisher Full Text | Free Full Text

19. Trivers RL: The evolution of reciprocal altruism. $Q$ Rev Biol. 1971; 46(1): 35-57. Publisher Full Text

20. Krause J, Ruxton GD: Living in groups (Oxford University Press, 2002). Reference Source

21. Maynard-Smith J: Group selection and kin selection. Nature. 1964; 201: 1145-1147. Publisher Full Text

22. Hamilton WD: The genetical evolution of social behaviour I. J Theor Biol. 1964; 7(1): 1-16.

PubMed Abstract | Publisher Full Text

23. Tamura K, Ihara Y: Classes of communication and the conditions for their evolution. Theor Popul Biol. 2011; 79(4): 174-183. PubMed Abstract | Publisher Full Text

24. Karban $\mathrm{R}$, Shiojiri $\mathrm{K}$, Ishizaki $\mathrm{S}$, et al.: Kin recognition affects plant communication and defence. Proc R Soc Lond B. 2013; 280(1756): 20123062. PubMed Abstract | Publisher Full Text | Free Full Text

25. Charnov EL, Krebs JR: The evolution of alarm calls: Altruism or manipulation? 
Am Nat. 1975; 109(965): 107-112.

Publisher Full Text

26. Sherman PW: Alarm calls of Belding's ground squirrels to aerial predators: Nepotism or self-preservation? Behav Ecol Sociobiol. 1985; 17(4): 313-323. Publisher Full Text

27. da Silva KB, Mahan C, da Silva J: The trill of the chase: Eastern chipmunks call to warn kin. J Mammal. 2002; 83(2): 546-552.

Publisher Full Text

28. Shelley EL, Blumstein DT: The evolution of vocal alarm communication in rodents. Behav Ecol. 2005; 16(1): 169-177.

Publisher Full Text

29. Pfeiffer W: Distribution of fright reaction and alarm substance cells in fishes. Copeia. 1977; 1977(4): 653-665.

Reference Source

30. Williams GC: Measurement of consociation among fishes and comments on the evolution of schooling. Pub Mus Michigan State Univ Biol Ser. 1964; 2(7): 349-384.

Reference Source

31. Williams GC: Natural selection: Domains, levels, and challenges. (Oxford University Press, 1992)

Reference Source

32. Chivers DP, Brown GE, Ferrari MCO: The evolution of alarm substances and disturbance cues in aquatic animals. In: Chemical ecology in aquatic systems. eds C. Brönmark \& L. A. Hansson (Oxford University Press, 2012).

33. von Frisch K: Zur Psychologie des Fisch-Schwarmes. Naturwissenschaften. 1938; 26(37): 601-606.

Publisher Full Tex

34. von Frisch K: Über einen Schreckstoff der Fischhaut und seine biologische Bedeutung. Z Vgl Physiol. 1942; 29(1-2): 46-145.

Publisher Full Text

35. Kristensen EA, Closs GP: Anti-predator response of naive and experienced common bully to chemical alarm cues. J Fish Biol. 2004; 64(3): 643-652. Publisher Full Text

36. Barreto RE, Barbosa A, Giassi ACC, et al.: The 'club' cell and behavioural and physiological responses to chemical alarm cues in the Nile tilapia. Mar Freshw Behav Physiol. 2010; 43(1): 75-81.

Publisher Full Text

37. Barreto RE, Miyai CA, Sanches FHC, et al.: Blood cues induce antipredator behavior in Nile tilapia conspecifics. PLoS One. 2013; 8(1): e54642. PubMed Abstract | Publisher Full Text | Free Full Text

38. Mathis A: Alarm responses as a defense: Chemical alarm cues in nonostariophysan fishes. In: Fish defenses Volume 2: Pathogens, parasites and predators. eds G. Zaccone, C. Perriére, A. Mathis \& B. G. Kapoor) 323-386 (Science Publishers, 2009). Reference Source

39. Mathis A, Smith RJF: Chemical alarm signals increase the survival time of fathead minnows (Pimephales promelas) during encounters with northern pike (Esox lucius). Behav Ecol. 1993; 4(3): 260-265.

Publisher Full Text

40. Stabell OB, Lwin MS: Predator-induced phenotypic changes in crucian carp are caused by chemical signals from conspecifics. Environ Biol Fishes. 1997; 49(1): 139-144.

Publisher Full Text

41. Chivers DP, Smith RJF: Chemical alarm signalling in aquatic predator-prey systems: A review and prospectus. Ecoscience. 1998; 5(3): 338-352. Reference Source

42. Smith RJF: Alarm signals in fishes. Rev Fish Biol Fish. 1992; 2(1): 33-63. Publisher Full Tex

43. Mathis A, Chivers DP, Smith RJF: Chemical alarm signals: Predator deterrents or predator attractants? Am Nat. 1995; 145(6): 994-1005. Publisher Full Text

44. Chivers DP, Brown GE, Smith RJF: The evolution of chemical alarm signals: Attracting predators benefits alarm signal senders. Am Nat. 1996; 148(4): 649-659. Publisher Full Text

45. Cameron AM, Endean R: Epidermal secretions and the evolution of venom glands in fishes. Toxicon. 1973; 11(5): 401-410.

PubMed Abstract | Publisher Full Tex

46. Al-Hassan JM, Thompson M, Criddle RS: Composition of the proteinacous ge secretion from the skin of the Arabian Gulf catfish (Arius thallasinus). Mar Biol. 1982; 70(1): 27-33.

Publisher Full Tex

47. Chivers DP, Wisenden BD, Hindman CJ, et al:: Epidermal 'alarm substance' cells of fishes maintained by non-alarm functions: possible defence against pathogens, parasites and UVB radiation. Proc $R$ Soc Lond B. 2007; 274(1625): 2611-2619. PubMed Abstract | Publisher Full Text | Free Full Text

48. James $\mathrm{CT}$, Wisenden BD, Goater CP: Epidermal club cells do not protect fathead minnows against trematode cercariae: A test of the anti-parasite hypothesis. Biol J Linn Soc. 2009; 98(4): 884-890. Publisher Full Text

49. Wisenden BD, Smith RJF: The effect of physical condition and shoalmate familiarity on proliferation of alarm substance cells in the epidermis of fathead minnows. J Fish Biol. 1997; 50(4): 799-808.

Publisher Full Text
50. Dalesman S, Rundle SD, Bilton DT, et al.: Phylogenetic relatedness and ecological interactions determine antipredator behavior. Ecology. 2007; 88(10): 2462-2467. PubMed Abstract | Publisher Full Text

51. Schoeppner NM, Relyea RA: Damage, digestion, and defence: the roles of alarm cues and kairomones for inducing prey defences. Ecol Lett. 2005; 8(5): 505-512. PubMed Abstract | Publisher Full Text

52. Schoeppner NM, Relyea RA: When should prey respond to consumed heterospecifics? Testing hypotheses of perceived risk. Copeia. 2009; 2009(1): 190-194

Publisher Full Text

53. Mitchell MD, Cowman PF, McCormick MI: Chemical alarm cues are conserved within the coral reef fish family Pomacentridae. PLoS One. 2012; 7(10): e47428. PubMed Abstract | Publisher Full Text | Free Full Text

54. Mathuru AS, Kibat C, Cheong WF, et al:: Chondroitin fragments are odorants that trigger fear behavior in fish. Curr Biol. 2012; 22(6): 538-544. PubMed Abstract | Publisher Full Text

55. Brown GE, Adrian JC, Smyth E, et al:: Ostariophysan alarm pheromones: Laboratory and field tests of the functional significance of nitrogen oxides. $J$ Chem Ecol. 2000; 26(1): 139-154.

Publisher Full Text

56. Pfeiffer W, Riegelbauer G, Meier G, et al.: Effect of hypoxanthine-3(N)-oxide and hypoxanthine-1(N)-oxide on central nervous excitation of the black tetra Gymnocorymbus ternetzi (Characidae, Ostariophysi, Pisces) indicated by dorsal light response. J Chem Ecol. 1985; 11(4): 507-523. Publisher Full Text

57. Roh E, Mirza RS, Brown GE: Quality or quantity? The role of donor condition in the production of chemical alarm cues in juvenile convict cichlids. Behaviour. 2004; 141(10): 1235-1248.

Publisher Full Text

58. O'Connell-Rodwell CE, Wood JD, Kinzley C, et al.: Wild African elephants (Loxodonta africana) discriminate between familiar and unfamiliar conspecific seismic alarm calls. J Acoust Soc Am. 2007; 122(2): 823-830.

PubMed Abstract | Publisher Full Text

59. Coopersmith R, Leon M: Enhanced neural response to familiar olfactory cues. Science. 1984; 225(4664): 849-851.

PubMed Abstract | Publisher Full Text

60. Brown GE, Smith RJF: Fathead minnows use chemical cues to discriminate natural shoalmates from unfamiliar conspecifics. J Chem Ecol. 1994; 20(12): 3051-3061. PubMed Abstract | Publisher Full Text

61. Mateo JM: Recognition systems and biological organization: The perception component of social recognition. Ann Zool Fenn. 2004; 41: 729-745. Reference Source

62. Berejikian BA, Smith RJF, Tezak EP, et al: Chemical alarm signals and complex hatchery rearing habitats affect antipredator behavior and survival of chinook salmon (Oncorhynchus tshawytscha) juveniles. Can J Fish Aquat Sci. 1999; 56(5): 830-838. Publisher Full Text

63. Brown GE, Adrian JC, Patton T, et al: Fathead minnows learn to recognize predato odour when exposed to concentrations of artificial alarm pheromone below their behavioural-response threshold. Can J Zool. 2001; 79(12): 2239-2245. Publisher Full Text

64. Brown GE: Learning about danger: Chemical alarm cues and local risk assessment in prey fishes. Fish Fish. 2003; 4(3): 227-234. Publisher Full Text

65. Holmes TH, McCormick MI: Smell, learn and live: The role of chemical alarm cues in predator learning during early life history in a marine fish. Behav Processes. 2010; 83(3): 299-305. PubMed Abstract | Publisher Full Text

66. Chivers DP, Smith RJF: Fathead minnows, Pimephales promelas, acquire predator recognition when alarm substance is associated with the sight of unfamiliar fish. Anim Behav. 1994; 48(3): 597-605. Publisher Full Text

67. Thünken T, Meuthen D, Bakker TCM, et al:: Parental investment in relation to offspring quality in the biparental cichlid fish Pelvicachromis taeniatus. Anim Behav. 2010; 80(1): 69-74. Publisher Full Text

68. Lamboj A: Die Cichliden des westlichen Afrikas. (Birgit Schmettkamp Verlag, 2004)

Reference Source

69. Thünken T, Bakker TC, Baldauf SA, et al:: Active inbreeding in a cichlid fish and its adaptive significance. Curr Biol. 2007; 17(3): 225-229.

PubMed Abstract | Publisher Full Tex

70. Thünken T, Bakker TC, Baldauf SA, et al.: Direct familiarity does not alter mating preference for sisters in male Pelvicachromis taeniatus (Cichlidae). Ethology. 2007; 113(11): 1107-1112.

Publisher Full Text

71. Thünken T, Meuthen D, Bakker TC, et al.: A sex-specific trade-off between mating preferences for genetic compatibility and body size in a cichlid fish with mutual mate choice. Proc R Soc Lond B. 2012; 279(1740): 2959-2964. PubMed Abstract | Publisher Full Text | Free Full Text

72. Thünken T, Waltschyk N, Bakker TC, et al.: Olfactory self-recognition in a cichlid fish. Anim Cogn. 2009; 12(5): 717-724. PubMed Abstract | Publisher Full Tex 
Thünken T, Baldauf SA, Kullmann $\mathrm{H}$, et al.: Size-related inbreeding preference and competitiveness in male Pelvicachromis taeniatus (Cichlidae). Behav Ecol. 2011; 22(2): 358-362.

Publisher Full Text

74. Hesse S, Bakker TCM, Baldauf SA, et al:: Kin recognition by phenotype matching is family- rather than self-referential in juvenile cichlid fish. Anim Behav. 2012; 84(2): 451-457.

Publisher Full Text

75. Thünken T, Bakker TCM, Baldauf SA: "Armpit effect” in an African cichlid fish: Self-referent kin recognition in mating decisions of male Pelvicachromis taeniatus. Behav Ecol Sociobiol. 2014; 68(1): 99-104. Publisher Full Text

76. Meuthen D, Baldauf SA, Bakker TCM, et al:: Substrate-treated water: A method to enhance fish activity in laboratory experiments. Aquat Biol. 2011; 13(1): 35-40. Publisher Full Text

77. McLennan DA: Male brook sticklebacks' (Culaea inconstans) response to olfactory cues. Behaviour. 2004; 141(11): 1411-1424.

Publisher Full Text

78. Mehlis M, Bakker TCM, Frommen JG: Smells like sib spirit: Kin recognition in three-spined sticklebacks (Gasterosteus aculeatus) is mediated by olfactory cues. Anim Cogn. 2008; 11(4): 643-650. PubMed Abstract | Publisher Full Text
79. R Core Team: $\mathbf{R}$ : a language and environment for statistical computing. $\mathbf{R}$ Foundation for Statistical Computing, Vienna, Austria. 2014 Reference Source

80. Bourdeau PE, Johansson F: Predator-induced morphological defences as byproducts of prey behaviour: A review and prospectus. Oikos. 2012; 121(8): 1175-1190. Publisher Full Text

81. Kats LB, Dill LM: The scent of death: Chemosensory assessment of predation risk by prey animals. Ecoscience. 1998; 5(3): 361-394. Reference Source

82. Ward AJW, Hart PJB: The effects of kin and familiarity on interactions between fish. Fish Fish. 2003; 4(4): 348-358. Publisher Full Text

83. Hesse S, Thünken T: Growth and social behavior in a cichlid fish are affected by social rearing environment and kinship. Naturwissenschaften. 2014; 101(4): 273-283.

PubMed Abstract | Publisher Full Text

84. Langen $\mathrm{K}$, Schwarzer J, Kullmann $\mathrm{H}$, et al:: Microsatellite support for active inbreeding in a cichlid fish. PLoS One. 2011; 6(9): e24689. PubMed Abstract | Free Full Text

85. Meuthen D, Baldauf SA, Thünken T: Fish activity data: Update 1. figshare. 2014. Data Source 


\title{
Open Peer Review
}

\section{Current Peer Review Status: ? ?}

\section{Version 2}

Reviewer Report 02 June 2014

https://doi.org/10.5256/f1000research.4502.r4957

(C) 2014 Sabelis M. This is an open access peer review report distributed under the terms of the Creative Commons Attribution License, which permits unrestricted use, distribution, and reproduction in any medium, provided the original work is properly cited.

\begin{abstract}
Maurice W Sabelis
Institute for Biodiversity and Ecosystem Dynamics (IBED), University of Amsterdam, Amsterdam, The Netherlands

We have read the revised article carefully but feel our original comments still apply. We have no further suggestions for how the authors could bring about improvements.
\end{abstract}

Competing Interests: No competing interests were disclosed.

I confirm that I have read this submission and believe that I have an appropriate level of expertise to confirm that it is of an acceptable scientific standard, however I have significant reservations, as outlined above.

Reviewer Report 30 May 2014

https://doi.org/10.5256/f1000research.4502.r4901

(c) 2014 Rubenstein D. This is an open access peer review report distributed under the terms of the Creative Commons Attribution License, which permits unrestricted use, distribution, and reproduction in any medium, provided the original work is properly cited.

\section{Dustin Rubenstein}

Department of Ecology, Evolution and Environmental Biology, Columbia University, New York, NY, USA

The authors have improved the clarity of the paper, but I still have reservations about the underlying premise of the study.

Competing Interests: No competing interests were disclosed. 


\section{I confirm that I have read this submission and believe that I have an appropriate level of expertise to confirm that it is of an acceptable scientific standard, however I have significant reservations, as outlined above.}

\section{Version 1}

Reviewer Report 02 November 2012

https://doi.org/10.5256/f1000research.150.r336

(C) 2012 Sabelis $\mathbf{M}$ et al. This is an open access peer review report distributed under the terms of the Creative Commons Attribution License, which permits unrestricted use, distribution, and reproduction in any medium, provided the original work is properly cited.

\section{Maurice W Sabelis}

Institute for Biodiversity and Ecosystem Dynamics (IBED), University of Amsterdam, Amsterdam, The Netherlands

\section{Paulien JA de Bruijn}

Institute for Biodiversity and Ecosystem Dynamics (IBED), University of Amsterdam, Amsterdam, The Netherlands

\section{Martijn Egas}

Institute for Biodiversity and Ecosystem Dynamics (IBED), University of Amsterdam, Amsterdam, The Netherlands

Meuthen et al. describe the results of experiments to test whether the cichlid fish Pelvicachromis taeniatus discriminates between alarm cues produced by kin and non-kin upon being injured by a predator.

They manipulated alarm cues (as a proxy of predation risk) in three treatments by exposing individual fish to one of the following: (1) Alarm cues derived from kin (from familiar and unfamiliar siblings); (2) Alarm cues derived from unfamiliar, unrelated conspecifics (non-kin); (3) Distilled water to control for disturbance effects upon introduction. They showed that activity of fish receiving alarm cues from treatment 1 and 2 was reduced compared to the control (treatment 3), but familiarity of siblings (treatment 1 ) and kinship (treatment 1 vs 2 ) had no effect on activity. Meuthen et al. conclude that $P$. taeniatus fish do not discriminate between alarm cues from kin and non-kin. Finally, they argue that kin selection can only play a role if this fish usually lives in groups of kin and that alarm cues are more likely to have evolved as a by-product of wound-healing or immune responses to pathogens colonizing cells wounded by predators.

While their experiments are clearly described and carefully designed, we question whether the question in the title of the paper by Meuthen et al. is well posed: Evolution of alarm cues: a role for kin selection? First, alarm cues represent public information and we see no reason why kin and nonkin should respond differently to these cues (except in the very special case where predation risk differs between kin and non-kin). Hence, we disagree where the authors state: "Higher sensitivity to 
kin-alarm cues may result in an improved response to predation, and thus higher survival of individuals related to the sender which in turn may increase the indirect fitness of the sender". Why would a higher sensitivity to kin alarm be expected in the first place? Second, the experiments by Meuthen et al. were designed such that they exclude the possibility for wounded fish to decide on what and how much to send depending on whether it is surrounded by kin or non-kin. This presupposes that the wounded fish has some form of control over the amount of alarm cues that are released. In our view this extent of this sender control is an essential target for kin selection. Thus, to answer the question posed in the title of the paper the experiments should have been designed so as to allow the potential sender to perceive who are the potential receivers and so as to measure the amount of alarm cues released depending on their environment.

\section{Side remarks:}

(1) In the Materials and Methods section the authors state: "(experimental stimuli) ... were introduced at the point of $1 \mathrm{~h} 15 \mathrm{~min}$ and then fish behavior was recorded for another hour. Thereafter, all experimental subjects were sized accurate to the nearest millimeter and weighed accurate to one milligram on an electrical precision scale (LC 2215, Sartorius, Germany)". However, the results of these measurements are not described in the paper.

(2) In the Results section the analysis focuses on activity as the difference in distance covered by the fish before and after application of the treatment. These values may differ (as they do between treatments 1 and 2 vs 3) due to differences before treatment, but the authors seem to assume that any difference in this activity parameter is due to differences after application of the treatment. We strongly suggest the authors to provide a statistical test to show that the distances before treatment were not significantly different among the three groups.

Competing Interests: No competing interests were disclosed.

\section{We confirm that we have read this submission and believe that we have an appropriate level of expertise to confirm that it is of an acceptable scientific standard, however we have significant reservations, as outlined above.}

Author Response 27 May 2014

Denis Meuthen, University of Bonn, An der Immenburg, Bonn, Germany

Sabelis et al. critically remarked "whether the question in the title of the paper is well posed". To our opinion the evolution of alarm cues is puzzling as their production is a costly process (individuals with higher condition produce more alarm cues). If individuals benefit from alarm cues while not contributing to the alarm system by producing own alarm cues, they would increase in number and ultimately eliminate this alarm signaling system from evolution. Kin-biased perception could solve this problem. In accordance with this hypothesis a recent paper shows that discrimination between kin and non-kin volatile chemical (alarm) cues occurs in plants (Karban et al. 2013). Moreover, several studies suggest that familiarity with alarm signals (O'Connell-Rodwell et al. 2007) or chemical cues ( Coopersmith \& Leon 1984, Brown \& Smith 1994) leads to improved responses. Along the hypotheses of other researchers concerning the role of kin selection in the evolution of mammalian alarm calls (Sherman 1977, Charnov \& Krebs 1975, Sherman 1985, da Silva et al. 2002) and alarm cues of fishes (Smith 1992), we therefore expect that individual fish should respond differently to alarm cues derived from kin and non-kin. 
Furthermore, Sabelis et al. suggest that "wounded fish have some form of control over the amount of alarm cues that are released, ultimately providing an essential target for kin selection ". If wounded fish had the control, this would be indeed a possibility. However, it is usually assumed that alarm cues are passively released. Alarm cues are putatively located in enclosed subepidermal club cells without external ducts, thus providing little opportunity for short-term variation in the released alarm cue amount. Accordingly, the only way for alarm cues to be released is the destruction of these cells by predators. Therefore, we focused on the receiver part, i.e. whether individuals are differentially sensitive towards kin and non kin alarm cues. One possible control by the sender might be differential long-term investment in club cell quantity depending on whether the sender is surrounded by relatives. In the present study all fish grew up in kin groups prior to trials, therefore, we exclude the possibility of differential investment based on the long-term sender environment.

Following Sabelis et al. side remarks we included additional analyses regarding fish sizes and activities before the treatment. These analyses showed that neither fish size nor weight nor prestimulus activity differed significantly among the three treatment groups.

Competing Interests: No competing interests were disclosed.

Reviewer Report 15 October 2012

https://doi.org/10.5256/f1000research.150.r335

(C) 2012 Rubenstein D. This is an open access peer review report distributed under the terms of the Creative Commons Attribution License, which permits unrestricted use, distribution, and reproduction in any medium, provided the original work is properly cited.

\section{Dustin Rubenstein}

Department of Ecology, Evolution and Environmental Biology, Columbia University, New York, NY, USA

The premise of this study is based on a theoretical model (Pollard 2010, Behavioral Ecology) demonstrating that receivers might use signaler identity to infer signaler reliability.

Such a framework may be appropriate when different signalers vary in their reliability, but in the case of alarm cues released from dead or wounded fish, the likelihood of dishonest alarm signals seem low. In other words, it is not clear why one would expect different responses to kin or non-kin alarm cues in these cichlid fish. Given that these cues must always honestly signal the presence of predator because of how they are released when an individual is wounded, fish would be expected to respond to any cue they find in the water. I therefore wonder if in this type of system that kin selection hypothesis is even appropriate to test. It is therefore not surprising to me that the authors find no difference in response to kin or non-kin alarm cues. I would have liked to have seen more discussion about the appropriateness of testing this model in this type of signal-receiver system. 
Competing Interests: No competing interests were disclosed.

\section{I confirm that I have read this submission and believe that I have an appropriate level of expertise to confirm that it is of an acceptable scientific standard, however I have significant reservations, as outlined above.}

Author Response 27 May 2014

Denis Meuthen, University of Bonn, An der Immenburg, Bonn, Germany

Rubenstein criticized the reference to the theoretical model by Pollard 2010. We realized that the reference to the Pollard paper was a bit misleading and may have caused confusion. In our revision, we replaced this aspect with a more detailed explanation of why we expect kin selection to play a role in the evolution of alarm cues. We now include other studies previously highlighting the potential role of kin selection in the evolution of alarm signals, including fish alarm cues. A particularly interesting example on plants shows that sagebrush induces strong anti-herbivore protection mechanisms when exposed to the volatile (alarm) cues of wounded close relative plants. In contrast, the anti-herbivore response was weaker when they were exposed to volatiles from distantly related plants.

Second, Rubenstein raised concerns that due to physiological restrictions of alarm cues in fish, dishonest alarm signals are unlikely. We fully agree with the referee. However, it was not our intent to convey that our study is based on the premise of the dishonest or honest alarm signals which are referenced by Pollard 2010. Instead, we focus on the question whether kin are able to respond more quickly towards a predator by being more sensitive towards kin alarm cues. For this purpose, in our revision we present an argument outlining that the recognition of kin alarm cues could be based on an indirect coupling of concurrently present kin-specific cues and alarm cues. Accordingly, fish could be able to discriminate between kin- and non-kin alarm cues based on learned kin recognition. This would not be surprising as kin recognition has been shown to be present in fishes and injuries caused by predators release numerous substances contained in very different areas of the prey body.

Competing Interests: No competing interests were disclosed. 
The benefits of publishing with F1000Research:

- Your article is published within days, with no editorial bias

- You can publish traditional articles, null/negative results, case reports, data notes and more

- The peer review process is transparent and collaborative

- Your article is indexed in PubMed after passing peer review

- Dedicated customer support at every stage

For pre-submission enquiries, contact research@f1000.com 